\title{
Pengelolaan Standar Kesehatan Pada Rumah Ibadah Dalam Mencegah Penularan Covid-19 Di Kabupaten Tasikmalaya
}

\author{
Kosasih Adi Saputra, Eman Sungkawa, Alex Anis Ahmad \\ Universitas Siliwangi Tasikmalaya \\ Email: kosasih.adisaputra@unsil.ac.id
}

\begin{abstract}
Abstrak
Pandemi covid 19 yang berdampak pada kehidupan masyarakat dunia menjadikan negara Indonesia sebagai negara yang cukup tanggap dalam mencegah penyebaran atau mengantipasi banyak lagi korban yang terpapar. Untuk itu, kalangan akademisi Perguruann Tinggi memiliki tanggungajwab dan kesadaran moral untuk mendedukasi pelayanan kesehatan di rumah ibadah berupa penyuluhan kesehatan serta pengelolaan Masjid dengan standar kesehatan yang tepat guna mencegah penyebaran virus corona. Kegiatan ini dilakukan sebagai bentuk tanggjawab moral pandemi warga negara dalam hal ini Perguruan Tinggi melalui LP2M dan dosen yang konsen pada bidang pengelolaan Masjid dan lingkungan sehat bagi masyarakat. Harapannya akan menjadi sebuah kebiasaan di masyarakat karena ada atau tidak adanya pandemi covid-19, pola hidup sehat di lingkungan ibadah itu tetap penting dilakukan. Hasil pengabdian ini dapat menunjukkan bahwa 1) Pengelolaan Masjid yang memenuhi standar kesehatan khususnya dalam mencegah penyebaran virus corana(covid-19) sudah dilakukan karena kesadaran akan pentingnya kesehatan dalam lingkungan masjid penelitian sudah ada atau sudah bagus tinggal diberikan kesadaran tentang 3 M,yang meliputi Mencuci tangan, Memakai masker dan Menjaga jarak. 2) Pembiasaan hidup sehat dalam lingkungan Masjid dan masyarakat sekitar untuk jangka panjang. Hal ini dilakukan dengan menggunakan fungsi masjid selain fungsi ibadah juga ada fungsi social, sehingga masjid tetap terawat serta di manfaatkan oleh jamaah dengan melalui protocol kesehatan.
\end{abstract}

Kata kunci : Standar Kesehatan, Rumah Ibadah, dan Penularan Covid-19

\section{Abstract}

The Covid 19 pandemic which has an impact on the lives of the world community has made Indonesia a country that is quite responsive in preventing the spread or anticipating many more exposed victims. For this reason, higher education academics have the responsibility and moral awareness to educate health services in places of worship in the form of health education and management of mosques with appropriate health standards to prevent the spread of the corona virus. This activity is carried out as a form of moral responsibility for the citizens' pandemic, in this case universities, through LP2M and lecturers who are concerned with managing mosques and a healthy environment for the community. The hope is that it will become a habit in society because of the presence or absence of the Covid-19 pandemic, a healthy lifestyle in an environment of worship is still important. The results of this service can show that 1) Management of mosques that meet health standards, especially in preventing the spread of the corana virus (covid-19) has been carried out because awareness of the importance of health in the research mosque environment already exists or is good, just be given awareness about 3M, which includes Wash hands, wear a mask and keep your distance. 2) Healthy living habits within the mosque and the surrounding community for the long term. This is done by using the function of the mosque in addition to the function of worship there is also a social function, so that the mosque is maintained and utilized by the congregation through health protocols.

Keywords: Health Standards, Houses of Worship, and Covid-19 Transmission

\section{PENDAHULUAN}

Pandemi covid-19 yang berdampak pada kehidupan masyarakat dunia menjadikan negara Indonesia sebagai negara yang cukup tanggap dalam mencegah penyebaran atau mengantipasi banyak lagi korban yang terpapar. Salah satu andem atau tempat yang menjadi perhatian pemerintah saat terjadi pendemi covid-19 adalah sarama rumah ibadah, ada yang tutup total bahkan ketika ada yang dibuka pun harus sesuai protokoler kesehatan. 
Rumah ibadah umat Islam yakni Masjid merupakan salah satu tempat yang paling banyak dan sering dikunjungi oleh para jamaah terlebih lagi pada waktu shalat.

Untuk itu, kalangan akamisi Perguruann Tinggi memiliki tanggungajwab dan kesadaran moral untuk mendedukasi pelayanan kesehatan di rumah ibadah berupa penyuluhan kesehatan serta pengelolaan andem dengan standar kesehatan yang tepat guna mencegah penyebaran virus corona. Bentuk kontribusi dari akademisi ini berupa kegiatan pengabdian pada masyarakat. Menurut Riduan (2016) "terdapat setidaknya tujuh bentuk pengabdian kepada masyarakat, diantaranya adalah kegiatan pelayanan kepada masyarakat. Kegiatan pelayanan masyarakat dapat diterapkan dalam berbagai aspek yang berkaitan langsung dengan kepentingan masyarakat. Salah satu kegiatan yang tidak dapat lepas dari kehidupan masyarakat adalah ibadah".

Lokasi pengadian yang menjadi mitra yakni rumah ibadah di wilayah di Kabupaten Tasikmaaya yang kurang terjangkau layanan edukasi pencegahan covid-19. Hal tersebut dikarenakan keterbatasan fasiltas dan informasi, kesadaran masyarakat yang belum maksimal sedangkan banyak warga yang keluar masuk kota lain yang sangat rawan penyebaran virus dan tidak memperhatikan standar kesehatan.

\section{BAHAN DAN METODE}

Mitra dalam pelaksanaan pengabdian pada masyarakat adalah DKM Nurul Ikhsan Desa Cisaruni Kecamatan Padakembang Kabupaten Tasikmalaya dan DKM Al-Muhajirin Desa Cilohohan Kecamatan Tanjungjaya Kabupaten Tasikmalaya. Dipilih karena lokasinya bukan di wilayah perkotaan sehingga memerlukan penanganan khusus akibat kurang terdedukasi dengan baik. Sasaran dari pengabdian ini adalah para pengurus DKM dan para jamaah disekitar lingkungan Masjid. Permasalahan yang dijadikan prioritas mitra disepakati bersama diantaranya:

1. Berdasarkan informasi belum adanya kajian tentang pengelolaan Masjid yang memenuhi standar kesehatan khususnya dalam mencegah penyebaran virus corana (covid-19), serta pembiasaan hidup sehat dalam lingkungan Masjid dan masyarakat.

2. Perlunya peranan Perguruan Tinggi melalui LP2M dan dosen yang konsen pada bidang pengelolaan Masjid dan lingkungan sehat bagi masyarakat. Ada atau tidak adanya pandemic covid-19, pola hidup sehat di lingkungan ibadah itu tetap penting dilakukan.

3. Diperlukan sebagai langah pemberian kapasitas dalam menghadapi persoalan di era "new normal", masyarakat yang menjadi mitra masih banyak yang keluar bebas keluar masuk dari berbagai kota karena sebagian besar juga bekerja di kota-kota besar.

HASIL

5.1 Pengelolaan Masjid yang memenuhi standar kesehatan khususnya dalam mencegah penyebaran virus corana (covid-19).

Berdasarkan hasil penelitian yang telah dilakukan pada saat shalat jumat dan ashar, kondisi masjid di wilayah Kabupaten Tasikmalaya, yaitu di wilayah Tanjungjaya dan Singaparna pada saat pandemic COVID-19. Dalam penelitian ini, tidak terjadi perubahan yang signifikan pada kerapatan saf shalatnya, dalam artian masyarakat masih memegang teguh mengenai karapatan saf shalat sebagai bagian dari kesempurnaan shalat.

Meskipun demikian, masyarakat tetap menerapkan protocol kesehatan seperti memakai masker, mencuci tangan pakai sabun, dan sebagainya dalam upaya antisipasi penularan virus COVID-19. Alasan masyarakat tidak menjaga jarak pada saat shalat yaitu karena mereka meyakini bahwa penduduk yang ada di wilayahnya tersebut tidak ada yang melakukan urbanisasi ke wilayah yang tercatat sebagai zona rawan penyebaran COVID-19. Pada bagian alas untuk shalat, masjid yang berada di Kecamatan Tanjungjaya 
masih menggunakan karpet, sedangkan masjid yang berada di Kecamatan Padakembang alas karpetnya sudah di gulung dan hanya menggunakan alas lantai saja, sehingga akan lebih memudahkan dalam pembersihannya.

\subsection{Pembiasaan hidup sehat dalam lingkungan Masjid dan masyarakat sekitar untuk jangka panjang.}

Pembiasaan hidup sehat dalam lingkungan Masjid dan masyaraka, TIM Pengabdian dengan DKM Nurul Ikhsan Cisaruni Padakembang Kabupaten Tasikmalaya dan DKM Al-Muhajirin Cilohohan Kecamatan Tanjungjaya Kabupaten Tasikmalaya melakukan kerjasama dalam melaksanakan program kegiatan. Mengingat lokasi pelaksanaan kegiatan sangat menunjang berjalannya kegiatan. Kerjasama yang dilakukan dalam rangka upaya membantu menyelesaikan permasalahan yang dihadapi yaitu keterbasannya sarana dan fasilitas serta informasi andemic covid-19, serta masih rendahnya kesadaran masyarakat akan pola hidup sehat, peran LP2M dan tim Pelaksana pengabdian pada masyarakat menjadi jembatan untuk menyelesaikan permasalahan tersebut.

Selanjutnya, diberikan pemahaman kepada masyarakat mengenai fungsi masjid bukan hanya sebagai tempat ibadah saja, akan tetapi masjid itu memiliki fungsi andem yang mesti di diterapkan dan kembangkan, diantaranya adalah masjid sebagai tempat atau sarana pendidikan, perekonomian dan sebagainya. Dan di masjid Al Muhajirin ini yang berada di Tanjungjaya sudah menerapkan konsep masjid yang memiliki fungsi ibadah dan fungsi social. Hal ini ditunjukan dengan adanya bagunan-bangunan sekolah, lapangan yang disewakan untuk acara pernikahan, rumah kontrakan yang berada di sekitar masjid dan semua itu dikelola oleh pengurus DKM untuk memakmurkan masyarakat disekitar masjid tersebut. Dalam hal ini bertujuan supaya bukan hanya masyarakat yang memakmurkan masjid, tetapi juga masjid memakmurkan masyarakat.

Dalam kegiatan ini juga masyarakat diberikan pemahaman mengenai paandemi, dimana masyarakat mesti manaati peraturan yang telah dibuat oleh pemerintah. Seperti menjaga jarak (social distancing), memakai masker dan hand sanitizer, dengan demikian ibadah yang dilakukan mesti dalam dua aspek, yaitu hubungan dengan Allah (Hablum minallah) dan hubungan dengan manusia (Hablum minannas). Walaupun kesadaran menggunakan masker pun belum, sehingga secara simbolis memberikan masker supaat dapat digunakan langsung oleh jamaah.

Dari uraian di atas, maka dapat disimpulkan bahwa masjid di daerah Kabupaten Tasikmalaya yang djadikan lokasi pengadian secara prinsip sebelum adanya pandemic covid 19 pun sudah melalukan upaya penjagaan masjid dengan baik. Namun, kesadaran dalam mengikuti protokoler kesehatan sebagaimana anjuran pemerintah belum ada. Misalnya dengan jaga jarak. Masjid di daerah ketika diberikan arahan untuk jaga jarak pada saf shalat, mereka memiliki panitsime tinggi, sehingga ketika melaksanakan pengabdian ini, kita secara perlahan saja menyampaikannya, menghindari perdebatan mengenai itu.

\subsection{Monitoring pengelolaan Masjid dan kesedaran hidup sehat}

Setelah diberikan arahan pada saat kegiatan pertama team pengabdian kemudian melakukan montoring pengelolaan masjid setelah diberikan arahan pada saat kegiatan pertama. Hasilnya masyarakat tetap menerapkan protocol kesehatan seperti memakai masker, mencuci tangan pakai sabun, dan sebagainya dalam upaya antisipasi penularan virus Covid-19. Kedisiplina masyarakat khususnya para jamaah jauh lebih meningkat dibandingkan pada saat survey awal dan kegiatan inti.

Untuk kesadaran menjaga jarak pada saat shalat yaitu karena mereka meyakini bahwa penduduk yang ada di wilayahnya tersebut tidak ada yang melakukan urbanisasi ke wilayah yang tercatat sebagai zona rawan penyebaran COVID-19. Pada bagian alas 
untuk shalat, masjid yang berada di Kecamatan Tanjungjaya masih menggunakan karpet, sedangkan masjid yang berada di Kecamatan Padakembang alas karpetnya sudah di gulung dan hanya menggunakan alas lantai saja, sehingga akan lebih memudahkan dalam pembersihannya.

\subsection{Evaluasi pengelolaan Masjid dan kesedaran hidup sehat di Masjid}

Evaluasi pengelolaan Masjid pemahaman dan kesadaran masyarakat akan pentingnya pengelolaan kesehatan di DKM Nurul Ikhsan Cisaruni Padakembang Kabupaten Tasikmalaya dan DKM Al-Muhajirin Cilohohan Kecamatan Tanjungjaya Kabupaten Tasikmalaya dilakukan dengan mewawancari ketua DKM dengan sebagain jamaah yang ada. Pada umumnya mereka mengucapkan terimakasih atas kedatangan team pengadian pada masyarakat Universitas Siliwangi.

Mereka berharap adanya tindak lanjut karena untuk memberikakan kesadaran pada masyarakat memang tidak mudah, perhatian pemerintah maupun Perguruan Tinggi, tidak cukup berupa materi maupun sosialisasi. Pada umumnya mereka ingin kehidupan normal kembali sebagaimana mestinya. Masyarakat ingin menjalani aktiviitas sosial dan ekonomi pada saat normal karena itu kebutuhan pokok.

Dalam hal beribadah pun masyarakat ingin khsusu terlebih lagi berjamaah di Masjid, apalagi Masjid sebagai rumah ibadah juga memiliki fungsi social, pendidikan dan ekonomi. Masyarakat tidak ingin dihantu rasa takut apalagi bila mendengar masjid sebagai claster penyebaran virus corana. Maka dar itu, team pengadian memberikan penjelasan dan menjauhkan masyarakat dari rasa takut itu.

\section{PEMBAHASAN}

Dari hasil pengabdian yang telah diuraikan pada bagian sebelumnya, tentang pengelolaan masjid dan pembiasaan hidup sehat di lingkungan tempat ibadah dan lingkungan masyarakat khususnya lokasi yang menjadi mitra pengabdian ini dapat diketahui bahwa berbagai tempat harus bersiap siaga karena manusia sebagai makhluk sosial tidak bisa hidup pada satu tempat yang statis dalam jangka waktu yang lama. Tempat ibadah seperti Masjid bagi umat Islam adalah ibarat kebutuhan pokok yang memiliki berbagai fungsi dan peranan. Sebagaimana menurut (Shihab 1996; Alwi, 2015) dikuktif Maharani (2019:31): Fungsi dan peran masjid bagi umat Islam, antara lain sebagai tempat ibadah; tempat konsultasi dan komunikasi tentang ekonomi, , dan budaya; tempat pendidikan; tempat santunan; tempat latihan militer dan persiapan alat-alatnya; tempat pengobatan para korban perang; tempat perdamaian dan pengadilan sengketa; aula dan tempat menerima tamu; tempat menawan tahanan perang; sebagai pusat penerangan dan pembelaan agama.

Masjid tidak dapat dipisahkan dari kegiatan keagamaan masyarakat. Ritual peribadatan seperti shalat berjamaah, pengajian bahkan hingga pendidikan keagamaan dilakukan di masjid. Dengan dijalankannya semua fungsi itu, masjid bisa kembali kepada peran yang sudah dilakukan dahulu: sebagai jami" tempat ibadah kolektif, tempat belajar (universitas) dan lembaga pendidikan, tempat diadakannya halaqah-halaqah sastra, mimbar tempat disiarkannya orientasi-orientasi keislaman, "parlemen" tempat permusyawarahan umat, tempat berkumpul untuk saling berkenalan, klub olahraga, tempat aktivitas dan oraganisasi reformasi masyarakat (Qardhawi, 2000). (Fauzzia, et al., 2018:82).

Dari uraian trersebut maka diketahui bersama tentang pengelolaan Masjid yang memenuhi standar kesehatan khususnya dalam mencegah penyebaran virus corana(covid19) sudah dilakukan karena kesadaran akan pentingnya kesehatan dalam lingkungan masjid penelitian sudah ada atau sudah bagus tinggal diberikan kesadaran tentang $3 \mathrm{M}$,yang meliputi Mencuci tangan, Memakai masker dan Menjaga jarak.

Pembiasaan hidup sehat dalam lingkungan Masjid dan masyarakat sekitar untuk jangka panjang. Hal ini dilakukan dengan menggunakan fungsi masjid selain fungsi ibadah juga ada fungsi social, sehingga masjid tetap terawat serta di manfaatkan oleh jamaah 
dengan melalui protocol kesehatan. Berbicara kesadaran dan pola hidup sehat di Indonesia tentunya belum mendaptkan infromasi yang cukup menggembirkan. Menurut data UNICEF, $44,5 \%$ total seluruh penduduk Indonesia belum memiliki akses pembuangan tinja yang layak dan 63 juta masyarakat Indonesia masih buang air besar sembarangan atau $24 \%$ dari total penduduk Indonesia pada tahun 2012 masih melakukan buang air besar (BAB) Sembarangan. Lebih lanjut, UNICEF menyatakan bahwa sanitasi dan perilaku kebersihan yang buruk, serta minum air yang tidak aman berkontribusi terhadap $88 \%$ kematian anak akibat diare diseluruh dunia (Triyono, A. 2014) dalam (Sutarto, Minerva Nadia Putri A.T1, Dian Isti Angraini, \& Nasution, 2019:18).

Dari uraian di atas maka dapat diketahui bahwa dalam menghadapi situasi yang serba sulit ini, pengurus Masjif berupaya untuk semakimal mungkin menyesuaikan dengan keadaan tanpa mengurangi esensinya sebagai rumah ibadah. Namun ada saja nilai positif yakni meningkatnya kesadaran akan pentingnya pengelolaan rumah ibadah dari sisi penciptaan lingkungan yang bersih dan sehat, agar terdindar dari penyebaran covid-19.

\section{KESIMPULAN DAN SARAN}

Secara umum, pengabdian ini dapat disimpulkan bahwa Peran DKM Al-Muhajirin Unsil Dalam Mencegah Penularan Covid-19 Melalui Pembinaan Pengelolaan Masjid Yang Sesuai Standar Kesehatan di Kabupaten Tasikmalaya dilakukan dengan berbagi pengalaman antara DKM Al-Muhajarin Universitas Siliwangi yang benar melakukan upaya dalam pencegahan virus corana dengan standar kesehatan sebagiaman anjuran pemerintah pusat maupun pemerintah daerah. Memberikan arahan dan sharing walaupun kesadaran kesehatan di dua masjid yang menjadi sampel telah melalukan itu, kecuali pembatasan saf shalat.

Sementara itu, kesimpulan khususnya sebagai berikut:

1) Pengelolaan Masjid yang memenuhi standar kesehatan khususnya dalam mencegah penyebaran virus corana (covid-19) sudah dilakukan karena kesadaran akan pentingnya kesehatan dalam lingkungan masjid penelitian sudah ada atau sudah bagus tinggal diberikan kesadaran tentang $3 \mathrm{M}$,yang meliputi Mencuci tangan, Memakai masker dan Menjaga jarak.

2) Pembiasaan hidup sehat dalam lingkungan Masjid dan masyarakat sekitar untuk jangka panjang. Hal ini dilakukan dengan menggunakan fungsi masjid selain fungsi ibadah juga ada fungsi sosial, sehingga masjid tetap terawat serta di manfaatkan oleh jamaah dengan melalui protocol kesehatan.

\section{UCAPAN TERIMA KASIH}

Terlaksananya pengabdian ini kami ucapkan terimkasih kepada ketua pertama team pengabdian ini yakni Drs. H. Nana Setialaksana yang dalam perjalanan beliau pensiun sebagai dosen tetap di Unsil. Juga kepada anggota yang lebih dulu meninggalkan dunia ini yakni almarhum Dr. H. Eman Sungkawa, S.H.,M.H. semoga diterima disisi Allah SWT. Juga kepada 2 mahasiswa yang membantu teknis kegiatan yakni Septian Cahya Azhari dan Wildan Imammudin. Terakahir kami ucapkan juga kepada 2 mitra kami yakni Ust Didik Ketua DKM Nurul Ikhsan Bantarpayung, Desa Cisaruni Kecamatan Padakembang Kabupaten Tasikmalaya dan Bapak Nunu Nuryawan Ketua DKM Al-Muhajirin Kampung Pojok Rt 15 Rw 03 Desa Cilolohan Kecamatan Tanjungjaya Kabupaten Tasikmalaya.

\section{DAFTAR PUSTAKA}

Aliyyah, R., RSP Fauziah, \& N Asiyah. (2017, April ). Peningkatan cinta lingkungan dan pemberdayaan masyarakat pedesaan melalui program pengabdian masyarakat. Media Pengabdian kepada Masyarakat Qardhul Hasan, Volume 3 Nomor 1.

Fauzzia, W., Finna Sofiani, Diana Nadia Shaleha, Nitta Amelia M, Ria Delia, Wida Rubianti, et al. (2018, Februari). Pengabdian Kepada Masyarakat Bakti Sosial Bersama Jamaah 
Masjid Fatmah Hidayah. JURNAL ABDIMAS BSI Jurnal Pengabdian Kepada Masyarakat, Vol. 1 No. 1 , 81-86.

Fidiyani, R. (Tahun 2016). Dinamika Pembangunan Rumah Ibadah Bagi Warga Minoritas Di Jawa Tengah . Prosiding Seminar Nasional Multi Disiplin IImu \& Call For Papers Unisbank (Sendi_U) Ke-2 2016 Kajian Multi Disiplin IImu dalam Pengembangan IPTEKS untuk Mewujudkan Pembangunan Nasional Semesta Berencan (PNSB) sebagai Upaya Meningkatkan Daya Saing Global (pp. 501-510). Semarang: Fakultas Hukum Universitas Negeri Semarang (UNNES).

Maharani, D. (2019, Oktober ). Pendampingan Pengurus Remaja Masjid Dalam Pengelolaan Administrasi. PARAHITA ABDIMAS Jurnal Pengabdian Masyarakat, Vol. 1 No. 1, 3039.

Marinda, D., \& Yustini Ardillah. (2019). Implementasi Penerapan Sanitasi Tempat-tempat Umum Pada Rekreasi Benteng Kuto Besak Kota Palembang . Jurnal Kesehatan Lingkungan Indonesia, 89 - 97.

Nugraheni, P. L., \& Rasha. (2019, Maret). Penyuluhan Sanitasi Higiene Dan Phbs Pada Masyarakat Kawasan Candi Batujaya, Sebagai Dasar Membangun Desa Wisata Yang Bersih Dan Sehat. JPkM : Jurnal Pengabdian kepada Masyarakat, Vol. 1 No.1 , 23-31.

Rahayu, S., Khairunnisa, Dini W. Hapsari, \& Eksi Puspita R. (2019, Juni ). Penyusunan Laporan Keuangan Rumah Ibadah Sesuai Dengan Psak 45 Pada Siswa-Siswi Sekolah Menengah Kejuruan Mathlaul Anwar Program Studi Akuntansi. Dinamisia - Jurnal Pengabdian Kepada Masyarakat, Vol. 3(Special Issue ), 135-143.

Sutarto, Minerva Nadia Putri A.T1, Dian Isti Angraini, \& Nasution, H. (2019). Pemberdayaan Masyarakat Dalam Meningkatkan Sarana Sanitasi Rumah Tangga (Jambanisasi) Di Desa Binaan Margoagung Kecamatan Jatimulyo Lampung Selatan. Logista -Jurnal IImiah Pengabdian kepada Masyarakat, Vol 3. No.1 , 17-20.

\section{LAMPIRAN}

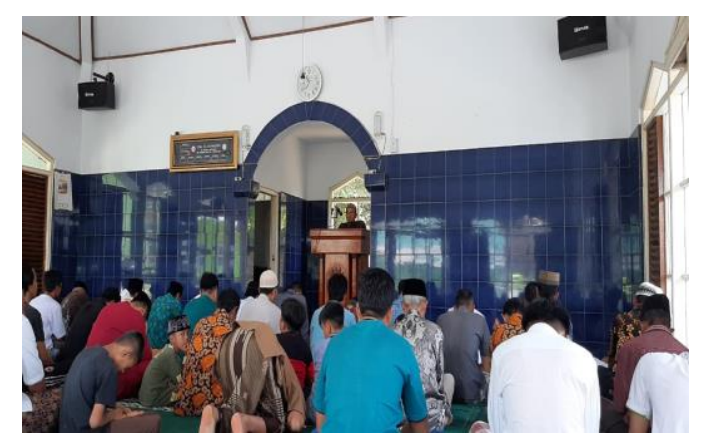

Gambar 1. Saf Shalat Jumat tidak melakukan jaga jarak

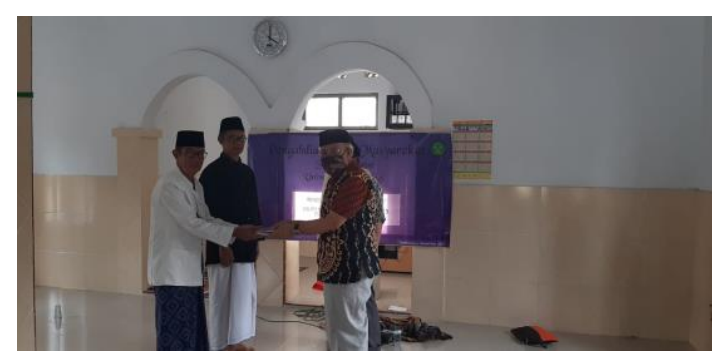

Gambar 2. Penyerrahan Masker secara simbolis 